\title{
SOCIAL MOVEMENTS OF WOMEN SEEN THROUGH SOCIAL MANAGEMENT THEORY: a study of the academic literature on social movements with participation of women in Tocantins
}

\section{MOVIMENTOS SOCIAIS DE MULHERES À LUZ DA GESTÃO SOCIAL: um estudo da literatura acadêmica sobre movimentos sociais com participação de mulheres no Tocantins}

\begin{abstract}
Helga Midori Iwamoto
Doutora em Administração pela Universidade Presbiteriana Mackenzie. Professora Adjunta II na UFT (Fundação Universidade Federal do Tocantins). Professora do Mestrado Profissional em Gestão de Políticas Públicas da UFT Coordenadora do Mestrado Profissional em Administração Pública na UFT (PROFIAP) helga@uft.edu.br

Airton Cardoso Cançado

Doutor em Administração pela UFLA (2011), Mestre em Administração pela UFBA (2004) e graduado em Administração com Habilitação em Adm. de Cooperativas pela UFV (2003) Professor do Programa de Pós-graduação em Desenvolvimento Regional, do Mestrado Profissional em Gestão de Políticas Públicas e do Curso de Administração da UFT airtoncardoso@yahoo.com.br

Mário Vasconcellos Sobrinho Mestre em Planejamento do Desenvolvimento pelo Núcleo de Altos Estudos Amazônicos (NAEA) da Universidade Federal do Pará (2000) PhD em Estudos do Desenvolvimento (2007) pelo Centre for Development Studies (CDS), University of Wales Swansea (Reino Unido) Pós-doutor em Gestão Pública e Governo (2015) pela EAESP da Fundação Getúlio Vargas (FGV) mariovasc@ufpa.br
\end{abstract}

\begin{abstract}
Women's social movements are formed as networks of collaboration and neighborhood (SACCHET, 2009) and later are formalized as associations, cooperatives, NGOs and Social Organications of Public Interest. Throughout this process of formalization, it is necessary to glimpse whether the forms of organization of these groups of women reproduce the ideals of traditional strategic administration or bring with them practices, principles and objectives linked to Social Management. According to Cançado, Tenório and Pereira (2011), these would be: collective decision-making, dialogue, intelligibility, transparency and emancipation. There is significant literature documenting the differences between male and female management styles. Buttner (2001), Chao and Tian (2013) and De Mascia (2015), for example, report that women managers had more relational skills, greater ability to work in teams, and greater focus on integrative strategies in conflict resolution. Other characteristics of the female management style would be informality/accessibility (CUBA; DECENZO; ANISH, 1983) and the incentive to participation (BOWEN; HISRICH, 1986; NEIDER, 1987; BRUSH, 1992). It remains to be found in women's social movements if there is a predominance of women's management styles and if
\end{abstract}


these styles resemble the principles of social management. The objective of this study is to verify among the social movements with female participation in Tocantins if there are in their management practices traces of Social Management. The survey of the existing movements was made through search in the academic databases Scielo, IBICT and Proquest. The methodology is qualitative, based on literature review on the subjects in question.

Palavras-chave: Social Movements of Women. Social Management. Tocantins.

\title{
Resumo
}

Os movimentos sociais de mulheres se formam como redes de colaboração e vizinhança (SACCHET, 2009) e se oficializam posteriormente como associações, cooperativas, ONGs e OSCIPs. Ao longo deste processo de formalização, faz-se necessário vislumbrar se as formas de organização destes grupos de mulheres reproduzem os ideais da administração estratégica tradicional ou trazem consigo as práticas, princípios e objetivos vinculados à gestão social. Segundo Cançado, Tenório e Pereira (2011), estes seriam: a tomada de decisão coletiva, a dialogicidade, a inteligibilidade, a transparência e a emancipação. Existe literatura expressiva documentando as diferenças entre os estilos masculinos e femininos de gestão. Buttner (2001), Chao e Tian (2013) e De Mascia (2015), por exemplo, relatam que as mulheres gestoras tinham mais habilidades relacionais, maior capacidade de trabalhar em equipe e maior foco em estratégias integrativas na resolução de conflitos. Outras características do estilo feminino de gestão seriam a informalidade/acessibilidade (CUBA; DECENZO; ANISH, 1983) e o incentivo à participação (BOWEN; HISRICH, 1986; NEIDER, 1987; BRUSH, 1992). Resta verificar nos movimentos sociais de mulheres se há predominância de estilos femininos de gestão e se esses estilos possuem traços de semelhança com os princípios da gestão social. O objetivo deste trabalho é verificar dentre os movimentos sociais com participação feminina no Tocantins se há em suas práticas de gestão características da gestão social. O levantamento dos movimentos existentes foi feito por meio de busca nas bases de dados acadêmicas Scielo, IBICT e Proquest. A metodologia é qualitativa, baseada em revisão de literatura sobre os temas em questão.

Palavras-chave: Movimentos Sociais de Mulheres. Gestão Social. Tocantins.

\section{Introduction}

\author{
Maria, Maria \\ É um dom, uma certa magia \\ Uma força que nos alerta \\ Uma mulher que merece \\ Viver e amar \\ Como outra qualquer \\ Do planeta \\ Maria, Maria \\ É o som, é a cor, é o suor \\ É a dose mais forte e lenta \\ De uma gente que ri
}


Quando deve chorar

E não vive, apenas aguenta

Mas é preciso ter força

É preciso ter raça

É preciso ter gana sempre

Quem traz no corpo a marca

Maria, Maria

Mistura a dor e a alegria

Mas é preciso ter manha

É preciso ter graça

É preciso ter sonho sempre

Quem traz na pele essa marca

Possui a estranha mania

De ter fé na vida

Milton Nascimento \& Fernando Brant (1978)

Women's Social Movements have gained visibility and prominence because of their importance for income generation and female empowerment. These movements often begin in the form of networks of collaboration and neighborhood, being formalized later as associations, cooperatives, NGOs and OSCIPs.

Throughout this process of formalization, it is necessary to glimpse whether the forms of organization of these groups of women reproduce the ideals of traditional strategic management or bring with them, even in an unintentional way, the practices, principles and objectives linked to the Social Management Theory. According to Cançado, Tenório and Pereira (2011), these would be: collective decision-making, dialogue, intelligibility, transparency and emancipation.

There is significant literature documenting the differences between male and female management styles. Buttner (2001), Chao and Tian (2013) and De Mascia (2015), for example, report that women managers had more relational skills than the rest of the sample, greater ability to work in teams, and greater focus on integrative strategies in resolution of conflicts. Other characteristics of the female management style would be informality / accessibility (Cuba, Decenzo, Anish, 1983) and the incentive to participation (Bowen, Hisrich, 1986, Neider, 1987; Brush, 1992).

It is necessary to verify in the Social Movements of women if there is predominance of feminine styles of management and if these styles have traces of similarity with the principles of Social Management. The objective of this study is to verify among the Social Movements with a 
major female participation in Tocantins if there are in their management practices characteristics of Social Management.

The search for existing movements was made through research in the academic databases Scielo, IBICT and Proquest. The methodology is qualitative, based on literature review on the themes in question: Social Movements (SM); Women's Social Movements (WSM); WSM examples in the World, in Brazil and in Tocantins and Social Management. At the end, a discussion is carried out about the Social Management characteristics of WSM.

In the sections that follow, the literature reviews cited are presented.

\section{Social movements}

Gohn (2011), one of the leading exponents of Brazilian scientific production on Social Movements, stated that the brazilian production on the subject was still incipient. It can be deduced by means of a more recent search in the Scielo portal that this statement is still true, since only 63 articles with the exact expression "movimentos sociais" only in the title were found (SCIELO, 2019).

Touraine (1978), the world's main exponent of New Social Movements Theory, believes that a Social Movement (SM) generally can be characterized by three criteria: identity, opponent and project. The project dimension involves the theme of central concern between the movement and its opponent.

For Touraine (1985), the SM are a special kind of social conflict between well-defined opponents, whose focus is the social control of the main cultural patterns. According to him, the approach is centered on the representation of social actors who are simultaneously oriented by their culture and involved in structural conflicts. He differentiates classist SM and NSM, because the traditional ones were based on class diferentiation, according to marxist theory. The NSM, on the other side, are constituted by identity agendas like sexual orientation, environment, women and ethnic empowerment, among others.

He also believes that the old Social Movements were limited by the belief that there are only two opponents (elite vs. subalterns) in societies holding revolutions that were studied in classical SM Theory. In addition, it was believed according to the classic SM theory that 
individuals did not have individual means of acting against the system, being oppressed by its structure. In this way, the only way to build a revolution would be by means of the class struggle.

For Touraine (1997), while traditional movements are oriented by class struggle, NSM are guided by the substantive defense and realization of fundamental human rights. However, each minority or social group defends these rights by attending to the specific demands of its segment. In addition, each movement develops its own methods and approaches that contemplate their specific struggles. Some examples of NSM are advocacy movements for quality in education, health, public safety and the like.

Melucci (1989) also differentiates the NSM from class struggle movements, arguing that the forms of action of Social Movements have changed because the changes in forms of labor exploitation and domination have changed. In the past, domination and exploitation occurred through the simple appropriation of the results of labor. Nowadays, it occurs by manipulating organizations, information, cultural symbols and interpersonal relationships.

The author also provides a historical overview of the theories on SM. He points out that the structural theories of the 1970s explain why a movement establishes itself but does not describe how it operates concretely. On the other hand, those who work with the Theory of Resource Mobilization see only the operational side, but not the motivations. Melucci (1989) believes that the two paradigms are complementary, but, unfortunately, the Resource Mobilization researchers consider their theories as global theories about SM.

In the 1980s onwards, Melucci considers that there was a dispersion of Social Movements due to the proliferation of different cultural groups in societies. This multiple and diverse struggle has taken the place of the traditional class struggle, using the new networks that have become possible through the new information technologies. The author argues that current societies must know how to live with their internal social conflicts without aspiring to a synthesis or collapsing.

Continuing the time line, Alexander (1998), in relation to other studies on Social Movements, reports that a historical interpretation of the revolutions has always been made. In these revolutions, according to the author, the oppressed always seek to replace an oppressive form of state model with a similar one, arguing that the results will be different due to differences in intentionalities. This is illustrated metaforically by Orwell (2007 [ 1945]), where a group of farm animals take hold of the management of a farm and gradually reproduce the oppression perpetrated 
formerly by humans. According to Touraine (1978), this is precisely the difference between the class struggle SM and the NSM, because the last ones only seek to lead the processes of historicity, not necessarily through State power. For this author (op. cit), the historicity is constituted by the majority cultural orientations by which society normatively organizes its relations with its environment.

Taking into account the context of Social Movements in Latin America, Gohn (2011) reports that in the 1990s, indigenous movements stood out in the Brazilian context. From the 2000s onwards, she observed that there had been a revival of neighborhood community movements, mainly in Mexico and Argentina. Other examples pointed out by the author appeared with the maturation of manifestations of insurgents like the picketers in Argentina, coca growers (in Bolivia and Peru) and Zapatistas in Mexico. In Brazil, the Landless Rural Workers Movement and the Via Campesina Movement, inspired by opponents of the military regime during the 1970s and 1980s and by the Liberation Theology movement, are cited.

Other trends pointed out by the author in Latin America are the recent interaction between rural and urban Social Movements and the politicization of environmental movements. As examples of the latter, there is the movement against the installation of paper industries in Uruguay and against mining in Argentina. In Brazil, environmentalists joined popular movements in the cases of transposition of São Francisco River, in the movements of people affected by construction of dams and in defense of small farmers.

There are also trends as the achievements of black movement in terms of quotas in universities and student finance policies. Other struggles and strikes have also developed within the general framework of the student movement in Mexico, Chile and Brazil, in defense of the quality of basic and higher education and against corruption in the sector.

The justification for their existence, according to Gohn (2011), is the ability to diagnose social reality, constructing alternatives in a propositional way. In addition, they contribute to the awareness, mobilization and formation of pressure groups in society. They can also, through partnerships with similar Social Movements, make social control of public institutions more effective.

In the following section, we will present examples and characteristics of different Social Movements of Women around the world and also in Brazil. It may be seen in the next section that 
since their beginning in the $17^{\text {th }}$ century they present traits of the NSM, mainly the identity/ human rights agenda and the refusal of overthrowing the State power by authoritarian means.

\section{Social movements of women in the world and in Brazil}

According to Alves and Pitanguy (1994), one can point out the beginnings of feminist Social Movements since the 17th century (USA) and XVIII (France and England). Ferree and Mueller (2004) point out, as characteristics common to these movements, the struggle against mechanisms of oppression in order to grant access to opportunities based on gender, either explicitly intentional or not within these movements.

In the United States, for example, Ann Hutchinson gathered a congregation of women in her home to raise awareness of the misogyny in Calvinism. She was sentenced to the banishment of her community in 1637.

In France, at the time of the French Revolution, women did not see their rights to their own bodies and property to be covered by the Declaration of the Rights of Man and the Citizen. Therefore, they handed over to the General Assembly in 1789 a document claiming these rights. Unsuccessfully, Olympe de Gouges (1997 [1791]) insists and drafts the Declaration on the Rights of Woman and Citizen, extending the rights of the Declaration of Human Rights in 17 articles that did not address women. She was condemned by that in 1793 .

In England, Mary Wollstonecraft (1792) wrote the Defense of Women's Rights, contesting the natural differences in character or intellect between the sexes. She demanded that guidelines for education should aim self-realization for all human beings, inspired by Rousseau (1995 [1762]), except for the differentiation by sex as defended by the male author.

The universal suffrage movement, in turn, began in 1848 at the Seneca Falls Convention in the USA, with the publication of a feminist paraphrase of the Declaration of Independence. In 1865, in England, John Stuart Mill presented a bill to provide universal suffrage. Due to the lack of institutional support for this project, British feminists had a wing that radicalized, denounced Suffragettes, carrying out protests with material damages.

In the first modern cooperative (1848), The Rochdale Society of Equitable Pioneers, located in Manchester, England, there was female vote. The cooperative consisted of 28 members, 
one of whom was a woman (HOLYOAKE, 2008). Probably the first woman to exercise the right to vote in a collective space in England.

Pereira and Cançado (2018) approach the concept of Social Management and the cooperative principles of 1848 , finding great affinity between Social Management and cooperativism. Similar work can be found in Cançado (2016), when it approximates cooperativism to principles of Solidarity Economy, finding similar results. In these organizations, since its origin there is no distinction between male and female votes.

Looking to the brazilian context, Alves and Pitanguy (1994) consider that the suffrage arrived later through the political articulation promoted by Professor Deolinda Daltro in 1910 in Rio de Janeiro and by the scientist Bertha Lutz in São Paulo in 1919. This articulation was expanded to the various Brazilian states in the form of state laws and was finally contemplated nationally by a Getúlio Vargas decree-law in 1932.

More recently in a world-wide scale, there has been a resumption of these movements due to the wars that have occurred since the beginning of the 20th century, forcing women to leave the labor market due to the lack of male labor. Taking advantage of this momentum, they mainly demanded the right to vote, property and divorce.

In many African countries in a state of civil war, there has been a significant increase in the number of women elected by women because of male participation in wars (PRESTAGE, 1991; ABDULLAH ET AL, 2010). In general terms, this increase in world terms was only effectively achieved by quotas policies in elective positions. In the case of Latin America, the Cupos Act in Argentina in 1991 was the first such regulation (ÁLVAREZ, 2012). In the Brazilian case, Sacchet (2009) points out that at that time only $10 \%$ of the Chamber of Deputies was occupied by women. Currently, Pains (2018) points out that this percentage is $10.5 \%$ and puts Brazil in position 152 in terms of female representation in federal elective positions.

On the other hand, Gohn (2007) points out that women are the majority in the public collective action movements, such as social welfare movements, struggle for better living conditions and drug prevention, but are still the largest victims of domestic violence. Since 1997 in Brazil, women have mandatorily been at least $30 \%$ of the candidates for elected positions (BRAZIL, 1997). In 2018, the Superior Electoral Court decided that at least 30\% of the resources of the partisan fund should be used in women's campaigns (TSE, 2018). 
Going back to the postwar context in the US, there was a setback in the role of women in society, leading Betty Friedan (2000) to criticize the expectation of feminine domesticity in her work The Feminine Mystique. Along with this backlash, Costain and Majstorovic (1994) reported that movements in favor of women's rights in the US receded in the 1960s, in conjunction with other movements of excluded groups such as Blacks and Latinos in defense of their civil rights. This expansion in Social Movements in general occurred due to the American rejection of civil society to the Vietnam War (JEFFORDS, 1989).

Gomes and Sorj (2014) report that, historically, the first feminist movements were formed in regions with high socioeconomic indicators (white women, high schooling, middle and upper classes) focusing on voting rights (suffrage), property, divorce abortion, public policies for family planning and public day care centers. Post-colonial feminist movements, in turn, began in the 1990s because women from other countries, ethnic groups belonging to other social groups did not identify with the majority feminist movements at the time (NASCIMENTO; MARTINS, 2012). Often, post-colonial demands had to do with multiple oppression due to social class, ethnicity, and gender, as is the case with Black women, Latinas and indigenous people around the world.

In other cases, such as that of Indian peasants (SHIVA, 1988) and indigenous Canadians (WILSON, 2005), feminists have joined environmental movements in order to promote the preservation of natural resources. In the Indian case, the struggle was for the preservation of the native seeds against the hegemony of the transgenic seeds of multinationals; in the case of the Canadians, was for the preservation of environmental reserves against mining and logging, as well as the organization of manifestos against the implementation of nuclear plants.

According to Costain and Majstorovic (1994), the major American feminist groups date back to the 19th and 20th centuries, such as the American Association of University Women (WASHINGTON, 1881), the National Federation of Women Workers and Entrepreneurs (KENTUCKY, 1919) and Women's Election League (WASHINGTON, 1920), National Women's Organization (WASHINGTON, 1966) and National Women's Political Caucus (WASHINGTON, 1971). It can be seen that the scope of these groups is quite varied, from gender equality to the promotion of female scientific production and women candidates for elective positions.

The performance of these groups is important because of the interface they promote between government and civil society. Examples of this were the national public consultation in 
1972 on access to credit in the United States, due to the denial or cut of financial credit to women who had changed marital status, as well as the Pregnancy Discrimination Act (1978), which prohibits companies to discriminate against pregnant women in hiring, evaluation and dismissal (COSTAIN; MAJSTOROVIC, 1994).

Within a current postcolonial feminist context, Ferree and Mueller (2004) argue that theories spread and diversify both through academic bases and through the migration of academics or militants themselves. These migrations, according to the authors, provide intellectual bridges and possibilities for action between various countries and continents, with possibilities for coalitions between local movements. These coalitions have been formalized through international bodies such as the International Women's Council, the Inter-American Commission of Women, the International Alliance for Women's Suffrage and the International Women's League for Peace and Freedom, thereby increasing their participation in decisions and sectors of the United Nations - UN and related entities. As an example of a post-colonial women's movement, although it is not a feminist movement itself, Gondorová (2014) states that women had a strong participation in the Tunisian Arab Spring movement, locally called the Jasmine Revolution (2010-2011). The author points out that, in the Arab world, there are differences in cultural patterns among women in the various countries that make up the group, often subsumed by a label and a Eurocentric bias. In the specific case of Tunisia, the author considers that the country has the most progressive Arab legislation in feminist terms, implemented by the first president Habib Bourguiba in 1957, in affinity with commercial partners like USA and Israel. However, traditional customs often overlap with current legislation.

In the case of Tunisia, the author reports a history of strong female participation in anticolonial and anti-authoritarian Social Movements, as witnessed against French colonization leading to independence in 1956, national union protests in 1978, national revolt against increase in the price of bread (caused by International Monetary Fund guidelines) in 1984 and the revolt against poor working conditions and compensation in Gafsa's phosphate mines (2008). Nevertheless, this participation still suffers resistance due to the generalized ideology in the society of separation between public sphere vs. public sphere between the sexes. Gondorová (2014) describes the process of female participation in movements as an alternating cycle in which there 
is only effective endorsement for them in revolutionary times. In the rest of the time, they are expected to return to their domestic and reproductive chores.

Another threat after the Jasmine Revolution is that the new government does not offer the legal guarantees to the women that the ousted government offered because of the immediate focus on job creation, public safety, economic development and the promulgation of the New Constitution, configuring a setback for Tunisian women. In addition, there has been a setback in the female representation in elective office in that country due to an Islamic majority of the Ehnanda party. However, the Islamic women felt they were contemplated, because the prohibition of the use of the Islamic veil that had been in force since 1956 was barred.

In the context of Latin America, Einwohner et al (2000) also exemplify the preponderant female participation in a non-feminist movement: The Mothers of the Plaza de Mayo in Argentina. They began the movement in April 1977, carrying out public protests denouncing the disappearance of friends and family due to the dictatorship. Initially their goals included recovering the the arrested people that disappeared alive. Currently, the focus of action is to bury their dead and punish those responsible for disappearances and torture.

Still in Argentina, another example is brought by Barker (2007), emphasizing that more than half of the Argentine Piquetero Movement is formed by women. However, as with most leftwing movements and guerrillas (except for the zapatistas), women's demands have been relegated to the background, thus prioritizing the objectives of class struggle (BLAY, 2001, 2012). One way of attracting women to the movement was the valorization discourse of the working family. One side effect of female adherence to traditional gender roles in left-wing movements is the attribution of typical female occupations such as cleaning, cooking, and secretarial duties.

Another movement that has female participation, in the Brazilian case, is the Landless Movement. In the early 1980s, women's participation in the movement was minimal because of the clause that only one member per family could be affiliated to unions linked to CONTAG (National Confederation of Agricultural Workers), usually the head of household (DEERE, 2003). In the author's view, another issue was that in the form of INCRA (National Institute for Colonization and Land Reform), until the year 2000, there was only one field in the form to designate the land holder. In general, the government officials chose male heads of household for this position. 
Due to these Brazilian retrograde positions, both in Social Movements and in the State, joint ownership of the land of couples is optional, while in other Latin American countries it is mandatory. This leads to discrepancies such as the possession of only $5 \%$ of Brazilian rural land being exclusively women owned, while $87.32 \%$ have exclusive male ownership (VILLELA, 2016). In Colombia, for example, $45 \%$ of the ownership of rural settler lands is joint (DEERE, 2004).

This exclusive male ownership is problematic mainly for the small farmers, where the work is joint and shared, but in case of separation, the family's livelihood is only in the hands of men. This phenomenon of the lack of focus on policies for access to female land ownership may be due to a lack of awareness of the importance of the right to individual female property by agents of the State and of Social Movements in the struggle for land (BONFIM, COSTA; LOPES, 2013). This right to land ownership makes possible the economic autonomy of the settlers, providing the resolution of situations of domestic violence.

Deere (2003) points out that the female participation in the Brazilian movements for land owning began in the 1980s, generating specific internal aspects such as the rural workers' movements. This participation was fostered mainly due to the dispute between CONTAG and CUT (Central Única dos Trabalhadores - Central Workers Union Confederation) by the unionized rural workers. As a result, the MMTR (Movement of Rural Women Workers) was created in 1986 jointly by CUT and CONTAG in a conciliation effort, working mainly in the North and Northeast regions.

According to Araújo (2017), in the South region, the Movement of Women Farmers, started in Santa Catarina, promoted the creation of the Movement of Peasant Women, which includes more women from the South and Southeast regions.

Some achievements of these women's movements were the protection of labor and social security rights in the 1988 Constitution. Sales (2007) emphasizes the importance of article 189, single paragraph of the Constitution on the equal rights of men and women in obtaining title to land or concession of land use for agrarian reform purposes.

In Deere's view (2003), as of 1989 the MST National Women's Commission lost functionality and women from the movement were encouraged to join the Movement of Peasant Women. On the other hand, the Articulation of Instances of South Rural Working Women 
promoted, together with CUT, an incentive movement for rural workers to declare themselves in the census and, together with the official bodies as workers, rather than housewives or unpaid family workers. In the same ideological line, in 1993, the CUT approved a quota system of 30\% for women in leadership positions at the national, state and regional levels.

Sales (2007), in turn, points out that in 1995, as a result of several articulations at the national level, the National Articulation of Rural Women Workers was born. After all these factors, in 2000, the possible option for the joint possession of the land to the settled couples, acquired through the Marcha das Margaridas (Daisies's March) in the same year, was achieved.

As can be seen throughout the performance of the various WSM, there are always progressive and consequent currents within the movements, often with female protagonism in the more conservative wings. What appears to be the greatest contribution of the movements themselves is the learning of women's participation in the public sphere and in organized instances of civil society. It is believed that this learning can lead to an improvement in the socio-economic conditions of the participants, making their participation even more qualified.

Another possible outcome is the formation of leadership in the new generations, in order to promote a virtuous circle of female participation in the public sphere. Although the new generations are suffering from a post-feminist backlash effect (MCROBBIE, 2004), it must be recognized that the feminist struggles of previous generations have brought about improvements in the socio-economic conditions of today's generations.

In the following section, some of the Social Movements with the participation of more expressive women in Tocantins are presented.

\section{The social movements of women in the Tocantins state, Brazil}

Most of the academic literature about Social Movements with significant participation of women in Tocantins State is in the form of articles published in congresses, theses, dissertations and articles of scientific journals outside Scielo, the main Brazilian portal of scholarly papers. There are few scientific articles dealing with the topic within the cited portal, which leads to the consideration that this literature is not achieving the most qualified journals in the Qualis System 
of CAPES, responsible for ranking national and international journals according to the Brazilian governmental criteria (CAPES, 2003).

Looking at the main women's movements in the state, Miranda (2014) points out as more important: The Movement of the Rural Workers, the Movement of the Babassu Coconut Women Breakers (MBCWB), the Movement of Women of Via Campesina and the women's groups within the Landless Workers' Movement. According to the author, these movements are articulated with the following state government agencies to advance the demands of women: the Women's Directorate, linked to the State Department of Social Defense; the State Council for Women's Rights; the Centers of Reference and Assistance to Women in Situation of Violence and the Specialized Police Stations in the Assistance to Women.

In the case of Axixá and São Miguel municipalities, Miranda and Santos (2014) found an expressive number of rural women affiliated in rural workers unions and vegetable extractivist associations, such as the MBCWB; in the urban environment of these municipalities, women were not organized as in rural areas by means of Social Movements. According to Araújo (2017), the MBCWB is linked at the regional level to the Babassu Coconut Interstate Movement, involving women from Pará, Maranhão, Tocantins, Goiás, Mato Grosso and Piauí.

Araújo (2017) says that the movement began to articulate in the region of the Middle Mearim, in Maranhão, due to the approval of State Law 2.979 (MARANHÃO, 1969), which limited the access of coconut breakers to Babassu trees that were inside the farms. Due to this mobilization, rights were obtained for the breakers in the 1988 Constitution, such as retirement at age 55 as rural workers and paid maternity leave. Currently, it is estimated that 200,000 families are supported by the Babassu economy (PIZZIO, 2014).

According to Dias (2016), in Tocantins, the largest representative of the movement, locally formalized as ASMUBIP (Regional Association of Rural Women Workers of Bico do Papagaio), with 3000 participants is Mrs. Raimunda Quebradeira. Before her deceasing (G1 Tocantins, 2018), she lived in the Sete Barracas settlement, in the municipality of São Miguel do Tocantins. Due to her leadership in the movement, she was awarded the title of Doctor Honoris Causa by the Federal University of Tocantins in a ceremony attended by the anthropologist Edgar Morin.

Another relevant movement in Tocantins with female participation is the Movement of the Affected by Dams (MAD), as reported by Parente (2015). The author studied the condition of the 
women who were resettled in Tocantins due to the construction of the Estreito Hydroelectric Power Plant on the border between Maranhão and Tocantins in 2012. According to the Estreito Energy Consortium (EEC), 3,710 families were affected by this project; for MAD, the total number of people affected was almost 5 thousand.

In many of the resettlements generated by the Estreito Power Plant, as reported by Parente (2016), the wells drilled by the Consortium provide poor quality water, due to the high salinity levels, which leads to the need for supply by water trucks. In times of rain, these trucks cannot reach the houses, which leads to days without water supply. This situation of poor-quality water and water scarcity is common in resettlement of those affected by dams, as reported by Laschefski (2011). Another issue is that the mandatory supply of the water trucks is for a limited period, leading to the impossibility of economic sustainability after the period of compulsory assistance by the consortium.

This negatively impacts families' economic and domestic sustainability capacity because they can no longer fish because of the distance and conditons of the dam lake water and cannot plant due to poor water quality in the wells. They also can no longer extract Babassu Coconut due to the construction of the dam. This situation leads to the male rural exodus, leaving mostly women in the precarious situation of the resettlement. In addition, resettlement breaks the relations of cooperation and work between relatives due to the relocation of families in different municipalities.

On the other hand, in the resettlements generated by the Lajeado Plant, Parente and Guerrero (2011) found women who considered themselves benefited by territorial reallocation. In these cases, they formerly did not have formal possession of the flooded land due to the construction of the dam.

Another type of WSM, but this time with feminine protagonism is the one of the artisans of golden grass. Sousa and Parente (2012) studied these artisans and saw that the income obtained from handicrafts and participation in associations of artisans of this type (ISPN, 2018) led to the empowerment of Jalapão women, having more voice in the domestic environment and in the sphere public.

As can be seen in the literature on women in Tocantins, the situation of local Social Movements with participation of women is still in its early stages, probably due to the state's low 
HDI. This socio-economic condition leads, on a first level, to difficulties of logistics and food for meetings with other Social Movements and representatives of public agencies. In addition, there is the difficulty of documentary formalization of internal organizations and procedures due to low schooling.

Other cultural issues also interfere, such as the naturalization of high birth rates and the idea that participation in Social Movements can only occur with the permission of husbands. This authorization is not necessary in the context of the women coconut breakers in the Bico do Papagaio, which began this economic activity from the earliest times of human occupation in the region, as a way of complementing the family's livelihood and often ended up obtaining income majority of their households.

In the case of coconut breakers, where there is a greater level of female empowerment, it can be seen the presence of characteristics of female management throughout the studied literature: focus on relational skills, teamwork and conflict resolution (BUTTNER, 2001; CHAO; TIAN, 2013; MASCIA, 2015); informality and accessibility (CUBA, DECENZO, ANISH, 1983) and the incentive to participation (BOWEN, HISRICH, 1986; NEIDER, 1987; BRUSH, 1992). A great example of this is the very figure of Dona Raimunda Quebradeira, which bringed together the coping skills, political and community articulation, accessibility, conciliation of conflicts and incentive to participation.

One can see similarities between the characteristics of female management with Social Management characteristics (horizontality in power relations, transparency in dialogue and wellunderstood interest), as will be seen in the following section.

\section{Social management in the social movements of women}

Social Management (SM) is a field of study developed in Brazil. This field originated in the 2000s and nowadays it has dozens of participating centers, a national meeting, some magazines that have the expression Social Management in the title and many others that have it in its scope. In Spanish language, a recent study identified only one work that could be classified as belonging to SM Theory according to Brazilian scholars (HERNANDÉZ; CANÇADO, 2017). In English language, there are some texts in Europe that approach the SM concept, but most anglophone 
papers are written by Chinese scholars, in which SM is defined contrarily to the Brazilian concept. In Brazil, it can be defined as horizontal participation without coercion. In China the vast majority of articles define social management as the management of society by the State (CANÇADO; MARINHO; IWAMOTO, 2018).

Resuming Cançado, Pereira and Tenório (2015), Social Management is based on collective decision-making without coercion, with the following characteristics: transparency, intelligibility, dialogue and emancipation. There are, therefore, some indications of Social Management in the WSM of the State of Tocantins.

It is important to emphasize that the mentioned enterprises can be classified, a priori, in some categories. Some come from resettlement caused by the construction of hydroelectric plants. In this case, the participants of the movements were relocated in "new" territorial spaces (Estreito and Lajeado Power Plants), which would justify their initial stage of development. Another category is production-based movements, such as Golden Grass and Babassu Coconut. The other enterprises are embedded in enterprises in which the "feminine" characteristic is not exclusive, such as the Landless Movement and Via Campesina, as well as the Rural Unions.

An important factor is the articulation of these movements with government agencies, which shows that participation takes place beyond the enterprise itself, with an impact on the public sphere.

As access to information was made through secondary data, the objective here is to outline a research agenda regarding the theme of women's movements in Tocantins. Thus, it is important in subsequent research to interpret the collective nature of decisions in these enterprises, as well as the decision-making process itself. To what extent intersubjectivity, intelligibility, transparency and emancipation in these relations can be perceived? Could features of Social Management be found in these experiences?

However, the issue of coercion appears as the central guiding question of the forthcoming interventions. To what extent are these women able to express themselves, to express their opinion and to decide according to what they think? How does this process of empowerment or emancipation occur?

According to the experiences presented some answers are possible. In order to achieve their rights (vote, land tenure, freedom ...), women gathered in movements, whose dynamics is through 
participation. Here is the first meeting point with social management. One can still say that these movements have faced stabilishment and their strength comes from ideas, based on voice, change and representativeness. Social management is a way by which the collective voice can bring change and generate representativeness. It is understood that they are movements with peculiar characteristics, but represent directly or indirectly about half of the planet population.

Social Management also enables social control. Social control here is understood as the control of the State by society (SILVA et al, 2017). In this sense, Social Management would be the means and Social Control would be the reason. Social control not only to oversees the government, but also demands change. Recent examples would be the protests of August 15, 2019 in which more than 200 Brazilian cities called for changes in educational policies. In this sense, the WSM can be considered actions of social control, since historically they fought for women's rights.

Finally, emancipation is central to SM, understanding emancipation as freeing the self from someone's tutelage and thinking on his/her own (CHAUÍ, 2011). This is a very representative situation of what happens inside the WSM.

Without the pretension of exhausting the subject, it can be said that there are indications that the WSM act in a logic of Social Management. Obviously, empirical studies are needed to advance these conclusions.

Following, the final considerations are presented.

\section{Final considerations}

It is possible to glimpse in these diverse movements that, although of informal way, not systematized, there are traces of emergent Social Management.

It is believed that as the Social Management principles are being improved in WSM, there is a possibility that these movements will be more effective in achieving their objectives.

For future research, qualitative methodologies focusing on the "listening" of these actors will be implemented, as well as the understanding of their contexts and their influence in the decision-making process. In a State marked by disputes and with large empty spaces, these issues 
should be understood in an ad hoc manner, because of the variety of movements and demands met by them.

\section{References}

ABDULLAH, H.J.; IBRAHIM, A.F.; KING, J. Women's voices, work and bodily integrity In pre-conflict, conflict and post-conflict reconstruction processes in Sierra Leone. IDS bulletin, v. 41, n. 2, pp.37-45, 2010.

ALEXANDER, J. C. Ação coletiva, cultura e sociedade civil: secularização, atualização, inversão, revisão e deslocamento do modelo clássico dos movimentos sociais. Revista brasileira de ciências sociais, v. 13, n. 37, pp.5-31, 1998.

ÁLVAREZ, G.A.D. Los movimientos sociales desde la perspectiva de las mujeres y pueblos indígenas. Un análisis desde la jurisprudencia de la Corte Constitucional colombiana. Revista de derecho, v. 37, n. 1, pp. 111-130, 2012.

ARAÚJO, L. Mulheres quebradeiras de coco babaçu e movimentos sociais. P2P e inovação, v. 3 n. 2, pp. 161-176, 2017.

BARKER, K. Women and Social Movements: engendering Argentina's Piquetero Movement. Undercurrent, v. 4, n. 1, pp. 57-68, 2007.

BLAY, E.A. 8 de março: conquistas e controvérsias. Estudos Feministas, v. 9, n. 2, pp.601-607, 2001.

BONFIM, E.G.; COSTA, M. C.; LOPES, M.J.M. Vulnerabilidade das mulheres à violência e danos à saúde na perspectiva dos movimentos sociais rurais. Athenea Digital - Revista de Pensamiento e Investigación Social, v. 13, n. 2, pp. 193-205, 2013.

BOWEN, D.D.; HISRICH, R.D. The female entrepreneur: A career development perspective. Academy of management review, v. 11, n. 2, pp.393-407, 1986.

BRASIL. Lei n ${ }^{\circ}$ 9.504, de 30/09/1997. Estabelece normas para as eleições. Available at <http://www.planalto.gov.br/cciviL_03/leis/L9504.htm>. Access in August 27, 2018.

BRUSH, C.G. Research on women business owners: Past trends, a new perspective and future directions. Entrepreneurship theory and practice, v. 16, n. 4, pp.5-30, 1992.

BUTTNER, E. H.Examining female entrepreneurs' management style: An application of a relational frame. Journal of Business Ethics, v. 29, n. 3, pp. 253-269, 2001. 
CANÇADO, A. C.; MARINHO, F. A.; IWAMOTO, H. M. Social Management: An Anglophone Perspective. International Conference on Democratic Governance in Developing World, 4, 2018, Rio de Janeiro, Anais..., Rio de Janeiro: EBAPE/FGV, 2018.

CANÇADO, A. C.; PEREIRA, J. R.; TENÓRIO, F. G. Gestão social: epistemologia de um paradigma. 2 ed. Curitiba: CRV, 2015, 216p.

CAPES (Coordenação de Aperfeiçoamento de Pessoal de Nível Superior). Qualis. 2003. Available at: <http://www.capes.gov.br/component/content/article?id=2550:capes-aprova-anova-classificacao-do-qualis $>$. Access in 27 ago. 2018.

CHAO, C.C.; TIAN, D. Keeping relationships positive or doing things right: bridging women leaders' conflict management strategies in non-profit organisations in Taiwan and the USA.

Chinese Management Studies, v. 7, n. 1, pp.94-110, 2013.

CHAUI, M. Cultura e democracia: o discurso competente e outras falas. 13. ed. São Paulo: Cortez, 2011, 368p.

CUBA, R.; DECENZO, D.; ANISH, A. Management practices of successful female business owners. American Journal of small business, v. 8, n. 2, pp. 40-46, 1983.

DE MASCIA, S. Are women better leaders than men? Human Resource Management International Digest, v. 23, n. 7, pp. 1-4, 2015.

DEERE, C. D. Women's land rights and rural social movements in the Brazilian agrarian reform. Journal of Agrarian Change, v. 3, n. 1-2, pp. 257-288, 2003.

DEERE, C. D. Os direitos da mulher à terra e os movimentos sociais rurais na reforma agrária brasileira. Rev. Estud. Fem., v. 12, n. 1, pp. 175-204, 2004.

DENZIN, N.K.; LINCOLN, Y. S. (Ed.)The Sage handbook of qualitative research. Newcastle upon Tyne, UK: Sage, 2011.

DIAS, L. O. Interseções de gênero: Mulheres quebradeiras de coco e a geração de vidas solidárias. Anais... IV Seminário de Trabalho e Gênero Protagonismo, ativismo, questões de gênero revisitadas, Universidade Federal de Goiás, Goiânia, 2016.

EINWOHNER, R.L.; HOLLANDER, J. A.; OLSON, T. Engendering social movements: cultural images and movement dynamics. Gender \& Society, v. 14, n. 5, pp. 679-699, 2000.

FERREE, M. M.; MUELLER, C. M. Feminism and the women's movement: A global perspective. The Blackwell companion to social movements, pp. 576-607, 2004.

FRIEDAN, B. The feminine mystique. New York: WW Norton \& Company, 2010. 
GOHN, M. G. Mulheres-atrizes dos movimentos sociais: relações político-culturais e debate teórico no processo democrático. Política \& Sociedade, v. 61, n. 1, pp. 41-70, 2007.

GOHN, M. G. Movimentos sociais na contemporaneidade. Revista Brasileira de Educação, v. 16, n. 47, pp. 333-361, 2011.

GOMES, C.; SORJ, B. Corpo, geração e identidade: a Marcha das Vadias no Brasil. Sociedade e Estado, p. 29, n. 2, pp. 433-447, 2014.

GONDOROVÁ, E. The position of women in post-revolutionary Tunisia and their role in political decision-making processes: between social movements, frustrations and administrative routine? Moving the Social, v. 5, n. 2, pp. 27-47, 2014.

GOUGES, O. Declaration of the Rights of Woman and Citizen. In: Kirsch, G.B. (Ed.). The West in global context: from 1500 to the present. London, UK: Pearson College Division, pp. 95-97, 1997 [1791].

HERNANDÉZ, A. R.; CANÇADO, A. C. Analisis de gestión socialbrasileña a través de la teoría de la decolonialidad. AOS, v.6, n.1, jan./jun. 2017, p. $25-43$ v.6, n.1, jan./jun. 2017, p. 25-43.

HOLYOAKE, G. J. Os 28 tecelões de Rochdale. 13 ed. Porto Alegre, Brazil: WS, 2008.

ISPN (Instituto Sociedade, População e Natureza). Associações de Artesãos de Capimdourado - Tocantins. Available at: <http://www.cerratinga.org.br/associacoes-de-artesaos-decapim-dourado-tocantins/>. Access in August 27, 2018.

JEFFORDS, S. The remasculinization of America: Gender and the Vietnam war. Bloomington, Indiana, EUA: Indiana University Press, 1989.

LASCHEFSKI, K. Licenciamento e equidade ambiental: as racionalidades distintas de apropriação do ambiente por grupos subalternos. In: ZHOURI, A. (Ed.) As tensões do lugar: hidrelétricas, sujeitos e licenciamento ambiental. Belo Horizonte, Brazil: UFMG, 2011.

MARANHÃO. Lei n. 2.979 de 17 de julho de 1969. Dispõe sobre as terras de domínio público e dá outras providências. In: GONÇALVES, M.F.C. A reinvenção do Maranhão dinástico. São Luís, Brazil: UFMA, PROIN, 2000.

MCROBBIE, A. Post-feminism and popular culture. Feminist media studies, v. 4, n. 3, pp. 255264, 2004.

MELUCCI, A. Um objetivo para os movimentos sociais? Lua Nova: Revista de Cultura e Política, 4917, pp. 49-66, 1989.

MIRANDA, C. M. Movimentos de mulheres, governança descentralizada e desenvolvimento regional no estado do Tocantins. Gênero na Amazônia, v. 5, n. 1, pp. 187-200, 2014. 
MIRANDA, C.M.; SANTOS, G. I. R. Mulheres do Bico do Papagaio: questões de gênero e desenvolvimento regional nos municípios de São Miguel e Axixá. RELEM: Revista Eletrônica Mutações, v.1, n. 1, pp. 74-87, 2014.

NASCIMENTO, M.; BRANT, F. Maria, Maria. Intérprete: Milton Nascimento. In: NASCIMENTO, M. Clube da Esquina 2. São Paulo: Emi-Odeon Brasil, 1978. Faixa 19.

NASCIMENTO, P. S.; MARTINS, A. R. M. Mulheres indígenas em movimentos sociais: novas práticas e desafios a partir da experiência das mulheres indígenas zapatistas. Somanlu, v. 12, n. 2, pp. 261-274, 2012.

NEIDER, L. A preliminary investigation of female entrepreneurs in Florida. Journal of small business management, v. 25, n. 3, pp. 22-37, 1987.

ORWELL, George. A revolução dos bichos. Rio de Janeiro: Companhia das Letras, 2007 [1945].

PAINS, C. Brasil tem menos parlamentares mulheres do que 151 países: Apenas 10,5\% do Congresso é feminino; país fica atrás até de Djibuti e Burkina Faso. Jornal O Globo, 07/03/2018. Available at: <https://oglobo.globo.com/sociedade/brasil-tem-menos-parlamentaresmulheres-do-que-151-paises-22462336>. Access in August 26, 2018.

PARENTE, T.G. Gênero e insustentabilidade de mulheres nos reassentamentos rurais da Usina Hidrelétrica de Estreito-Tocantins. Opsis, v. 15, n. 2, pp. 399-416, 2015.

PARENTE, T. G. P.; GUERRERO, O. F. O desempoderamento das mulheres dos reassentamentos rurais em Porto Nacional TO, Brasil. História Oral, v. 21, n. 4, pp. 173-197, 2011.

PIZZIO, A. Reconhecimento e resiliência no cotidiano de quebradeiras de coco babaçu. Estudos de Sociologia. v. 12, n. 0, pp. 1-6, 2014.

ROUSSEAU, J. J. Emílio: ou da educação. São Paulo, Brazil: Difusão, 1995 [1762].

PRESTAGE, J. L. In quest of African American political woman. The Annals of the American Academy of Political and Social Science, v. 51, n. 51, pp. 88-103, 1991.

SACCHET, T. Capital social, gênero e representação política no Brasil. Opinião Pública, v. 15, n. 2, pp. 306-332, 2009.

SALES, C. M. V. Mulheres rurais: tecendo novas relações e reconhecendo direitos. Estudos Feministas, v. 15, n. 2, pp. 437-452, 2007.

Scielo. Busca com a expressão exata "movimentos sociais" somente no título do artigo. Available at: <http://www.scielo.br/cgi-bin/wxis.exe/iah/>. Access in August 25, 2018. 
SHIVA, V. Staying alive: Women, ecology and survival in India. New Delhi, India: Kali for Women, 1988.

SILVA, F. R.; CANÇADO, A. C.; RODRIGUES, W.; BATISTA, W. L. Controle Social: a dinâmica da Teoria da Saída, Voz e Lealdade no Contexto da Administração Pública Brasileira. Emancipação, Ponta Grossa, v.17, n.1, p.108-125, 2017.

SOUSA, A.T.; PARENTE, T. G. A atividade artesanal do capim dourado na região do Jalapão: uma nova perspectiva para o empoderamento das mulheres. Anais... Encontro Nacional de História Oral. Rio de Janeiro, pp. 1-12, 2012.

TOURAINE, Alain. La voix et le regard: sociologie des mouvements sociaux. Paris: FeniXX, 1978.

TOURAINE, A. An introduction to the study of social movements. Social Research, 524, pp. 749-787, 1985.

TOURAINE, A. What is democracy? New York: Routledge, 1997.

TSE (Tribunal Superior Eleitoral). Aprovados critérios para distribuição do Fundo Eleitoral. Available at <http://www.tse.jus.br/imprensa/noticias-tse/2018/Maio/tse-aprova-criterios-paradistribuicao-do-fundo-eleitoral>. Access in August 27, 2018.

VILLELA, F. Propriedades comandadas por mulheres representam cerca de $5 \%$ da área rural. Rio de Janeiro: Agência Brasil, 2016. Available at:

$<$ http://agenciabrasil.ebc.com.br/direitos-humanos/noticia/2016-11/propriedades-de-terracomandadas-por-mulheres-representam-cerca-de>. Access in August 26, 2018.

WILSON, K. Ecofeminism and first nations peoples in Canada: linking culture, gender and nature. Gender, Place \& Culture, v. 12, n. 3, pp. 333-355, 2005.

WOLLSTONECRAFT, M. A vindication of the rights of woman: with strictures on political and moral subjects, Boston, USA: Peter Edes, Thomas and Andrews, 1792. Available at: $<$ https://play.google.com/store/books/details?id=qhcFAAAAQAAJ\&rdid=bookqhcFAAAAQAAJ\&rdot=1>. Access in November 17, 2018.

Recebido em 20/11/2018.

Aceito para publicação em 22/02/2019. 